\title{
One to Two Years
}

National Cancer Institute

\section{Source}

National Cancer Institute. One to Two Years. NCI Thesaurus. Code C148656.

An indication that something has lasted, or occurred during, one to two years. 